\title{
Potensi Pemberian Tocilizumab pada Pasien COVID-19 Di ICU RSUD Ulin Banjarmasin
}

\section{Potency of Tocilizumab Administration for COVID-19 Patients in ICU RSUD Ulin Banjarmasin}

Rohmantuah Trada Purba ${ }^{\otimes *}$, Mahendratama Purnama Adhi ${ }^{*}$, Rapto Hardian*, Andri Lumban Tobing ${ }^{*}$, Erna Kusumawardhani* ${ }^{* *}$

"Departemen Anestesiologi dan Terapi Intensif, Fakultas Kedokteran, Universitas Lambung Mangkurat/RSUD Ulin, Banjarmasin, Indonesia

***Departemen Pulmonologi dan Kedokteran Respirasi, Fakultas Kedokteran, Universitas

Lambung Mangkurat/RSUD Ulin, Banjarmasin, Indonesia

${ }^{\circledR}$ Korespondensi: rohmantuahtradapurba@gmail.com

\begin{abstract}
Background: Corona Virus Disease 2019 (COVID-19) is a pandemic disease that become global problem around the world. Clinical manifestation and severity of COVID19 varies for every patient. There was cytokine storm event that increase mortality dan morbidity in COVID-19 patients especially who's admitted to intensive care unit (ICU) where interleukin-6 (IL-6) plays an important role in this cytokine storm.

Case: We report 5 cases of COVID-19 patients with moderate to critical ill condition that given tocilizumab (TCZ) as IL-6 inhibitor which has therapeutic potency to reduce its mortality and morbidity.

Discussion: There are potential use of tocilicumab as IL-6 inhibitor in COVID-19 patients because its pathophysiology is related to IL-6 and cytokine storm that occurs. This event was monitored by evaluate the inflammation and coagulation disorder biomarker, such as c-reactive protein (CRP), lactate dehydrogenase (LDH), D-Dimer, ferritin and also the disease onset. Five patients that given TCZ, 3 patients were discharged and 2 others died.

Conclusion: TCZ has therapeutic potency if being given before 10 days of the disease onset. Further research needs to be done to prove the potency of therapeutic effect of tocilizumab and timing administration of this drug.
\end{abstract}

Keywords: cytokine storm; COVID-19; ICU; interleukine-6; tocilizumab 


\begin{abstract}
ABSTRAK
Latar Belakang: Corona Virus Disease 2019 (COVID-19) adalah penyakit pandemi yang menjadi masalah global yang melanda seluruh dunia. Manifestasi klinis dan tingkat keparahan penyakit COVID-19 sangat bervariasi. Pada pasien COVID-19 derajat kritis yang memerlukan perawatan di intensive care unit (ICU) telah ditemukan adanya proses badai sitokin yang meningkatkan mortalitas dan morbiditas. Interleukin-6 (IL-6) berperan dalam terjadinya badai sitokin.
\end{abstract}

Kasus: Berikut kami laporkan serial kasus 5 pasien COVID-19 terkonfirmasi positif derajat sedang-kritis yang diberikan tocilizumab (TCZ) sebagai suatu IL-6 inhibitor yang memiliki potensi terapi menurunkan mortalitas dan morbiditas pasien COVID-19 derajat berat-kritis.

Pembahasan: Dari 5 pasien yang diberikan TCZ, didapatkan hasil 3 pasien bisa pulang dan 2 pasien meninggal. Terdapat potensi pemberian IL-6 inhibitor karena dari patofisiologi penyakit COVID-19 yang berkaitan dengan IL-6 dan badai sitokin. IL-6 inhibitor dapat menurunkan mortalitas dan morbiditas dengan mencegah terjadinya badai sitokin. Hal ini diukur menggunakan evaluasi onset penyakit, kadar biomarker inflamasi dan gangguan koagulasi yang sering diteliti pada pasien COVID-19 seperti c-reactive protein (CRP), lactate dehydrogenase (LDH), D-Dimer dan ferritin.

Kesimpulan: Pemberian TCZ memiliki potensi efek terapeutik jika diberikan pada onset penyakit $<10$ hari. Perlu dilakukan penelitian lebih lanjut untuk menilai efek terapeutik dan timing pemberian yang tepat.

Kata Kunci: badai sitokin; COVID-19; ICU; interleukin-6; tocilizumab

\section{PENDAHULUAN}

Corona Virus Disease 2019 (COVID19) telah menjadi pandemi global yang mempengaruhi seluruh dunia. Data yang tercatat sampai tanggal 11 September 2020 sebanyak 28.040.853 kasus COVID-19 dan 906.092 kematian terkait COVID-19 telah dilaporkan kepada World Health Organization (WHO). ${ }^{1}$ Sedangkan di Indonesia, jumlah kasus terus bertambah dari 2 kasus konfirmasi COVID-19 pertama kali diumumkan pada tanggal 2 Maret 2020, hingga tanggal 11 September 2020 telah tercatat sebanyak 210.940 pasien dengan 8.544 kasus kematian. Di wilayah Kalimantan Selatan dilaporkan sebanyak 9.038 pasien terkonfirmasi dan 381 kasus kematian terkait COVID-19. ${ }^{2}$
Manifestasi klinis dan derajat keparahan penyakit COVID-19 sangat bervariasi, sekitar $80 \%$ kasus bergejala ringansedang dan sekitar 5\% atau lebih pasien dengan derajat berat-kritis memerlukan perawatan di intensive care unit (ICU) dengan tingkat mortalitas antara $1-2 \%{ }^{3}$ Pada kasus COVID-19 derajat berat, seringkali disertai suatu sindrom yang dikenal sebagai cytokine storm atau istilah lain cytokine release syndrome $(\mathrm{CRS}){ }^{4}$ Sindrom ini utamanya dimediasi oleh interleukin-6 (IL-6) yang berperan dalam meningkatkan morbiditas dan mortalitas pasien COVID-19. ${ }^{5}$ Karakteristik CRS adalah kadar IL-6 yang tinggi, demam tinggi dan pneumonitis hipoksik yang seringkali memerlukan ventilasi mekanik. ${ }^{6,7}$ 
Penanganan terhadap CRS ini menjadi bagian penting untuk menyelamatkan pasien COVID-19 derajat berat-kritis. Dikarenakan IL-6 memiliki peran penting dalam terjadinya CRS, maka terapi yang dapat menghambat jalur sinyal transduksi IL-6 diharapkan dapat menjadi salah satu pilihan dalam penanganan pasien COVID-19 derajat berat-kritis. ${ }^{8}$ Tocilizumab (TCZ) adalah obat jenis IL-6 inhibitor yang dilaporkan memiliki potensi mengurangi derajat keparahan COVID-19 pada beberapa clinical trial. ${ }^{9}$

TCZ sebenarnya merupakan suatu antibodi monoklonal yang telah digunakan secara luas untuk beberapa jenis penyakit auto-immune terutama rheumatoid arthritis. ${ }^{10}$ IL-6 merupakan mediator CRS yang menjadi target inhibisi TCZ, sehingga secara teori dapat menurunkan respons inflamasi, yang pada akhirnya akan meminimalkan komplikasi respirasi terutama acute respiratory distress syndrome (ARDS). ${ }^{11}$ Berikut kami laporkan serial kasus dari 5 pasien terkonfirmasi COVID-19 yang diberikan TCZ sebagai terapi tambahan COVID-19 yang dirawat di ICU COVID RSUD Ulin pada bulan Mei- Juli 2020.

\section{KASUS}

\section{KASUS 1}

Wanita usia 46 tahun, berat badan $55 \mathrm{~kg}$, terkonfirmasi COVID-19 dengan pemeriksaan positif real timepolymerase chain reaction (RT-PCR) hari perawatan ke-1. Pasien dirujuk masuk ICU dalam keadaan hipoksia dengan respiration rate (RR) 35 kali/menit $(\mathrm{x} / \mathrm{m})$, dan saturasi oksigen
$\left(\mathrm{SpO}_{2}\right)$ 80-85 \% dengan oksigen $\left(\mathrm{O}_{2}\right)$ non rebreathing mask (NRM) 15 liter/menit (lpm). Keluhan sesak yang dialami sejak 9 hari sebelum masuk rumah sakit disertai demam, batuk dan malaise, dan 5 hari terakhir keluhan semakin memberat. Pasien dengan ancaman gagal napas karena pneumonia dengan peningkatan biomarker inflamasi (Tabel 1).

Pasien diberikan terapi COVID-19 sesuai tingkat keparahan penyakit yaitu oksigenasi high flow nasal cannula (HFNC) $50 \mathrm{lpm}$ dan $\mathrm{FiO}_{2}$ 90\%, dan protokol terapi standar COVID-19 menurut Kemenkes yang terdiri dari antibiotik meropenem, levofloksasin, dan antiinflamasi azitromisin, hidroksiklorokuin, oseltamivir, metilprednisolon, omeprazole, asetilsistein, vitamin B Komplek, vitamin $C$, vitamin $D$, zink, probiotik, serta pemberian heparin intravena melalui syringe pump dosis $1000 \mathrm{IU}$ per jam. Pada hari perawatan ke-2 ditambahkan hepatoprotektor dan dua kali pemberian TCZ 400 mg dengan jeda waktu 12 jam. Setelah pemberian TCZ terjadi perbaikan kondisi dan dalam 6 hari berhasil dilakukan penyapihan flow dan $\mathrm{FiO}_{2}$ HFNC, dilanjutkan dengan pemberian $\mathrm{O}_{2}$ NRM $15 \mathrm{lpm}$ pada hari perawatan ke-7 dan menggunakan $\mathrm{O}_{2}$ simple mask (SM) pada hari perawatan ke-8. Pasien dipindahkan ke ruang perawatan isolasi pada hari ke-9. Total hari perawatan hingga pasien diperbolehkan pulang adalah 34 hari, sampai didapatkan hasil dua kali RTPCR negatif SARS-CoV-2 berturutturut. Serial foto toraks pasien dapat dilihat pada Gambar 1. 


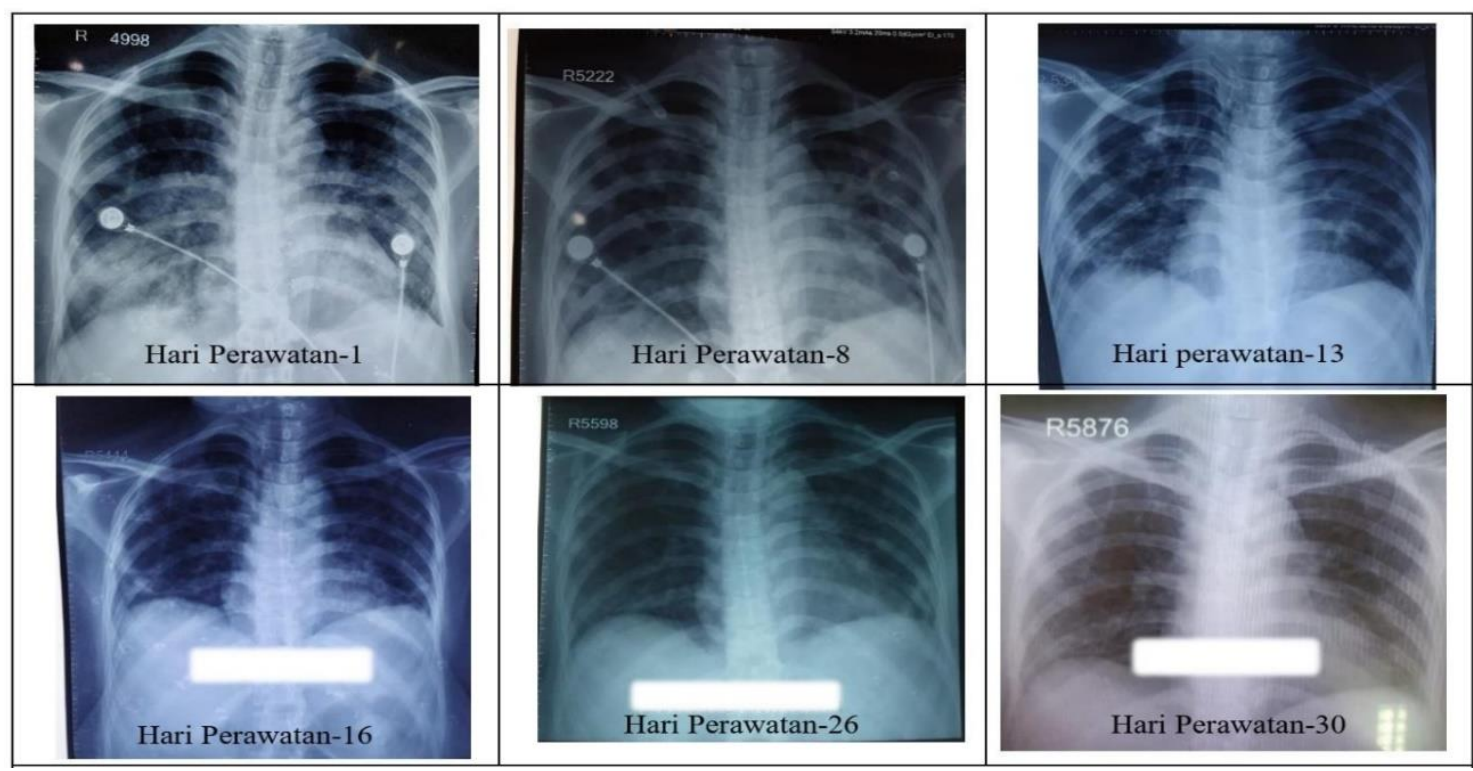

Gambar 1. Ronsen toraks evaluasi pasien kasus 1

Tabel 1. Parameter klinis dan laboratorium kasus 1

\begin{tabular}{|c|c|c|c|c|c|c|c|c|c|c|c|}
\hline Parameter & Hari-1 & $\begin{array}{l}\text { Hari- } \\
2\end{array}$ & $\mathrm{Hari-}_{3}^{-}$ & $\mathrm{Hari-}_{4}$ & $\frac{\mathrm{Hari}}{5}$ & $\underset{6}{\operatorname{Hari-}}$ & ${ }_{7}^{\text {Hari- }}$ & $\underset{8}{\text { Hari- }}$ & $\begin{array}{l}\text { Hari- } \\
13\end{array}$ & $\begin{array}{l}\text { Hari- } \\
19\end{array}$ & $\begin{array}{l}\text { Hari- } \\
30\end{array}$ \\
\hline RR $(10-20 \times / m)$ & 32 & 30 & 30 & 30 & 30 & 30 & 28 & 24 & 24 & 24 & 12 \\
\hline$\underset{\mathrm{C})}{\mathrm{Temp}}(36.5-37.5$ & 36,8 & 37,2 & 37,1 & 37.0 & 37,1 & 36,9 & 36,9 & 36,9 & 36.9 & 36,9 & 36,8 \\
\hline $\mathrm{Hb}(12-16 \mathrm{mg} / \mathrm{dL})$ & 12.5 & & 11.6 & 12,0 & & 12.5 & & & 11,8 & 12.1 & 12,4 \\
\hline $\begin{array}{l}\text { Leukosit (4-10 } \\
\text { ribu/ul) }\end{array}$ & 15,8 & & 14,6 & 11.9 & & 10,3 & & & 6,9 & 4,6 & 4,5 \\
\hline $\begin{array}{l}\text { Trombosit (150-450 } \\
\text { ribu/ul) }\end{array}$ & 450 & & 519 & 608 & & 585 & & & 374 & 256 & 299 \\
\hline PT (9.9-13.5 detik) & 12.1 & & 12.1 & 11.1 & 12,1 & 12.8 & 12,7 & 12,7 & 16,6 & 10,8 & \\
\hline $\begin{array}{l}\text { APTT (22.2-37 } \\
\text { detik) }\end{array}$ & 24.5 & & 64.6 & 27 & 111,4 & 26.5 & 24,8 & 24,8 & 37,4 & 27,9 & \\
\hline $\operatorname{INR}(<2)$ & 1.13 & & 1,13 & 1,03 & 1,13 & 1,2 & 1,05 & 1,05 & 1,59 & & \\
\hline $\begin{array}{l}\text { Ureum }(0-50 \\
\mathrm{mg} / \mathrm{dL})\end{array}$ & 34 & & 11 & 45 & & 41 & & & 21 & 15 & 13 \\
\hline $\begin{array}{l}\text { Creatinin } \\
\mathrm{mg} / \mathrm{dL})\end{array}$ & 0.72 & & 0.31 & 0,7 & & 0,60 & & & 0,6 & 0.58 & 0,5 \\
\hline GDS $(<200 \mathrm{mg} / \mathrm{dL})$ & 159 & & & 131 & & 167 & & & 90 & 99 & 84 \\
\hline SGOT (5-34 U/L) & 82 & & 97 & 31 & & 41 & & & 22 & 30 & 18 \\
\hline SGPT (0-55 U/L) & 167 & & 70 & 151 & & 114 & & & 51 & 79 & 24 \\
\hline $\begin{array}{l}\text { Albumin }(3,5-5.2 \\
\mathrm{gr} / \mathrm{dL})\end{array}$ & 2.6 & & & 2.8 & & 2.8 & & & 3,2 & 3,4 & 3,6 \\
\hline $\begin{array}{l}\text { Natrium }(136-145 \\
\text { Meq/L) }\end{array}$ & 134 & & 136 & 139 & & 132 & & & 138 & 140 & 141 \\
\hline $\begin{array}{l}\text { Kalium } \\
\text { Meq/L) }\end{array}$ & 4.1 & & 4.1 & 4,7 & & 5,1 & & & 4,1 & 4,1 & 4,0 \\
\hline $\begin{array}{l}\text { Clorida (98-107 } \\
\text { Meq/L) }\end{array}$ & 106 & & 106 & 107 & & 105 & & & 107 & 109 & 111 \\
\hline $\begin{array}{l}\mathrm{O}_{2} \text { Saturasi (75-99 } \\
\% \text { ) }\end{array}$ & 85 & 92 & 91 & 87 & 88 & 88 & 90 & 97 & 94 & & \\
\hline P/F Ratio & 57.5 & 64 & 62 & 48 & 81.6 & 108 & 88.3 & 128.3 & 133 & & \\
\hline LDH (125-220 U/L) & 846 & & & 410 & & 438 & & & & 207 & 192 \\
\hline CRP $(<5$ mg/dL) & 180 & & & 32,9 & & 8,0 & & & 0,4 & 0,5 & 0,2 \\
\hline $\begin{array}{l}\text { Ferritin (4-204 } \\
\text { ng/dL) }\end{array}$ & & & & 1360 & & 944 & & & 395,61 & 339,65 & 154 \\
\hline $\begin{array}{l}\mathrm{D}-\mathrm{Dimer}(<2 \\
\mathrm{mg} / \mathrm{L})\end{array}$ & & & 1.14 & 2.14 & & 5,64 & & & 1,49 & 0,98 & 0,78 \\
\hline
\end{tabular}

Volume 12, Nomor 3, Tahun 2020 
Keterangan: RR, respiration rate; PT, protrombin time; APTT, activated partial thromboplastin time; GDS, gula darah sewaktu; SGOT, serum glutamic oxaloacetic transaminase, SGPT, serum glutamic pyruvic transaminase; $\mathrm{LDH}$, lactate dehydrogenase; CRP, C-reactive Protein.

\section{KASUS 2}

Pasien laki-laki, usia 48 tahun, berat badan $63 \mathrm{~kg}$, terkonfirmasi positif COVID-19 dengan pemeriksaan RTPCR. Pasien masuk ICU dengan keluhan sesak, demam, batuk berdahak dan nyeri tenggorokan dialami sejak 7 hari. Kondisi pasien saat diterima memiliki gejala ringan-sedang, tidak demam, batuk dan nyeri tenggorokan, dengan RR 24-26 x/m, $\mathrm{SpO}_{2} \quad 98 \%$ menggunakan $\mathrm{O}_{2}$ nasal cannula (NC) 4 lpm. Didapatkan rhonki pada kedua sisi paru, dominan di regio inferior. Pasien diputuskan dirawat di ICU karena gambaran pneumonia dengan peningkatan biomarker inflamasi (Tabel 2), dan untuk antisipasi ancaman gagal napas.
Selama dirawat di ICU pasien diberikan terapi COVID-19 sesuai tingkat keparahan penyakit yaitu oksigenasi NC $4 \mathrm{lpm}$, dan protokol terapi standar COVID-19 serta penambahan heparin dosis 5000 IU per 12 jam subcutan (SC). Pada hari perawatan pertama di ICU, pasien mendapatkan terapi tambahan TCZ 400 mg dua kali pemberian dengan jeda waktu 12 jam. Pasien menunjukkan perbaikan klinis dan pada hari perawatan ke-3 pasien dipindahkan ke ruang perawatan isolasi. Total hari perawatan hingga pasien diperbolehkan pulang adalah 20 hari, sampai didapatkan hasil dua kali RT-PCR negatif SARS-CoV-2 berturut-turut. Serial foto toraks pasien dapat dilihat pada Gambar 2.

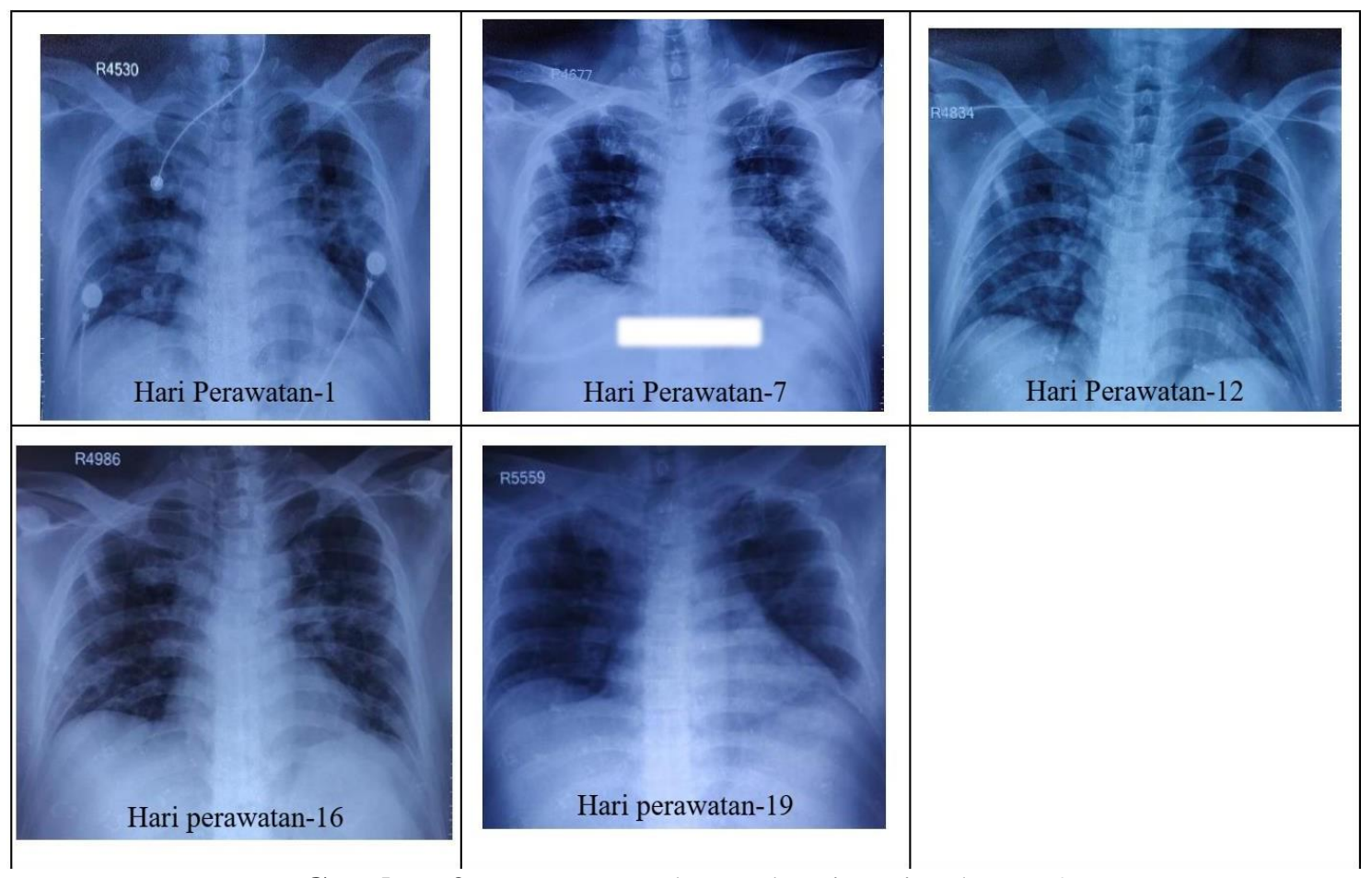

Gambar 2. Ronsen toraks evaluasi pasien kasus 2 
Tabel 2. Parameter klinis dan laboratorium kasus 2

\begin{tabular}{|c|c|c|c|c|c|c|c|c|c|}
\hline Parameter & Hari-1 & $\begin{array}{l}\text { Hari- } \\
2\end{array}$ & Hari-3 & Hari-4 & Hari-6 & Hari-9 & $\begin{array}{l}\text { Hari- } \\
12\end{array}$ & $\begin{array}{l}\text { Hari- } \\
16\end{array}$ & $\begin{array}{l}\text { Hari- } \\
19\end{array}$ \\
\hline $\mathrm{RR}(10-20 \mathrm{x} / \mathrm{m})$ & 24 & 24 & 24 & 20 & 20 & 18 & 18 & 16 & 16 \\
\hline Temp $\left(36.5-37.5^{\circ} \mathrm{C}\right)$ & 36,9 & 37,1 & 37,1 & 37,1 & 36,8 & 36,6 & 36,6 & 36,8 & 36,8 \\
\hline $\mathrm{Hb}(12-16$ mg/dL) & 14,6 & 14,1 & & 13,6 & 14,5 & 14,4 & 15,2 & 14,8 & 13,5 \\
\hline Leukosit (4-10 ribu/ul) & 11,2 & 11,2 & & 10,5 & 6,5 & 8,5 & 8,1 & 9,6 & 8,7 \\
\hline $\begin{array}{l}\text { Trombosit (150-450 } \\
\text { ribu/ul) }\end{array}$ & 221 & 398 & & 475 & 442 & 586 & 540 & 423 & 310 \\
\hline PT (9.9-13.5 detik) & 11,2 & 23,9 & 12,5 & 10,5 & & 10,6 & 10,8 & 10,7 & \\
\hline APTT (22.2-37 detik) & 49,2 & 30,8 & 29,5 & 2,76 & & 30,1 & 35,1 & 27,6 & \\
\hline $\operatorname{INR}(<2)$ & 1,09 & 2,31 & 1,08 & 0,97 & & 0,96 & 0,98 & 0,97 & \\
\hline Ureum $(0-50 \mathrm{mg} / \mathrm{dL})$ & 30 & 49 & 41 & & 34 & 24 & 21 & 32 & 28 \\
\hline $\begin{array}{l}\text { Creatinin } \\
\mathrm{mg} / \mathrm{dL})\end{array}$ & 0,65 & 1,1 & 0,9 & & 0,9 & 0,9 & 1,2 & 1 & 0,8 \\
\hline GDS $(<200 \mathrm{mg} / \mathrm{dL})$ & 131 & 111 & 95 & 92 & 86 & & & 87 & 127 \\
\hline SGOT (5-34 U/L) & 190 & 80 & 113 & & 178 & 112 & 74 & 51 & 76 \\
\hline SGPT (0-55 U/L) & 109 & 70 & 79 & & 135 & 134 & 107 & 85 & 88 \\
\hline $\begin{array}{l}\text { Albumin } \\
\mathrm{gr} / \mathrm{dL})\end{array}$ & & 3,5 & 3.0 & & & 3,2 & 3,7 & 3,8 & 3,7 \\
\hline $\begin{array}{l}\text { Natrium }(136-145 \\
\text { Meq/L) }\end{array}$ & & 136 & 136 & & & 137 & 137 & 137 & 139 \\
\hline Kalium $(3,5-5,1 \mathrm{Meq} / \mathrm{L})$ & & 4,7 & 4,4 & & & 4,3 & 4,8 & 5,7 & 4,3 \\
\hline Clorida (98-107 Meq/L) & & 106 & 107 & & & 104 & 105 & 106 & 108 \\
\hline $\mathrm{O}_{2}$ Saturasi (75-99 \%) & 97 & 96 & 97 & 99 & & 95 & & & \\
\hline P/F Ratio & 257 & 254 & 268 & 202 & & 242 & & & \\
\hline LDH (125-220 U/L) & & 641 & & 407 & 526 & 270 & 256 & 244 & 243 \\
\hline $\mathrm{CRP}(<5 \mathrm{mg} / \mathrm{dL})$ & & 129,2 & 13,9 & & 8,2 & 3,5 & 1,4 & 1 & \\
\hline Ferritin (4-204 ng/dL) & & $>2000$ & & & & & & 1376 & \\
\hline D-Dimer $(<2$ mg/L) & & 5,6 & & 0,2 & & & 0,7 & 0,19 & \\
\hline
\end{tabular}

Keterangan: RR, respiration rate; PT, protrombin time; APTT, activated partial thromboplastin time; GDS, gula darah sewaktu; SGOT, serum glutamic oxaloacetic transaminase, SGPT, serum glutamic pyruvic transaminase; $\mathrm{LDH}$, lactate dehydrogenase; $\mathrm{CRP}, \mathrm{C}-$ reactive protein.

\section{KASUS 3}

Pasien laki-laki, usia 52 tahun, berat badan $70 \mathrm{~kg}$, terkonfirmasi COVID-19 dengan pemeriksaan RT-PCR positif. Pasien dirujuk ke RSUD Ulin dengan keluhan sesak napas, demam dan nyeri tenggorokan sejak 10 hari. Pasien kemudian dirawat selama 2 hari di ruang perawatan.

Pada saat masuk, pasien dengan gejala sedang-berat, RR 28-32 x/m, dan $\mathrm{SpO}_{2}$ $92 \%$ menggunakan oksigen $\left(\mathrm{O}_{2}\right) \mathrm{NRM}$ $10 \mathrm{lpm}$. Didapatkan rhonki pada kedua lapang paru, dominan di bagian inferior, ditemukan gejala distress napas ditandai dengan penggunaan otot bantu napas dan tanda hipoksia. Hari pertama di ruangan perawatan pasien diberikan TCZ dengan dosis 400 mg di ulang 12 jam kemudian. Hari perawatan ke-3 pasien dipindahkan ke ruang ICU karena penurunan kondisi dan kemungkinan gagal napas yang memerlukan ventilator.

Selama dirawat di ICU pasien diberikan terapi COVID-19 sesuai tingkat keparahan penyakit yaitu oksigenasi HFNC $40 \mathrm{lpm}$ dan $\mathrm{FiO}_{2} 70 \%$, protokol terapai standar COVID-19 dan pemberian heparin dosis 1000-1350 IU per jam intravena. Terjadi perbaikan klinis selama perawatan di ICU, dan berhasil dilakukan penyapihan flow dan 
$\mathrm{FiO}_{2} \mathrm{HFNC}$. Oksigenasi diganti menjadi NC 4 lpm setelah 8 hari di ICU. Pasien kembali ke ruang perawatan biasa pada hari perawatan ke-10. Total hari perawatan hingga pasien diperbolehkan pulang untuk isolasi mandiri adalah 24 hari.

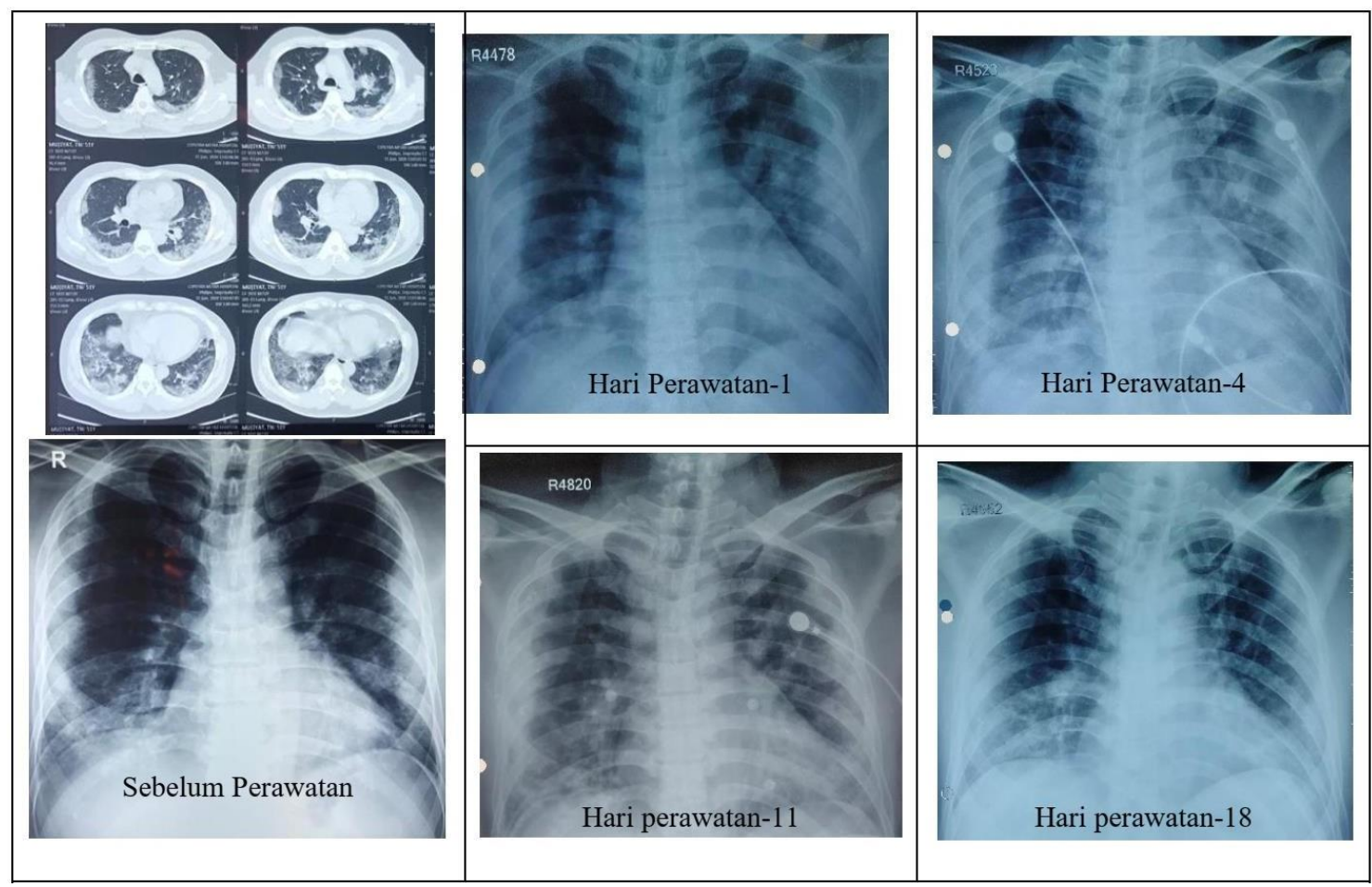

Gambar 3. Ronsen dan CT-Scan toraks evaluasi pasien kasus 3

Tabel 3. Parameter klinis dan laboratorium kasus 3

\begin{tabular}{|c|c|c|c|c|c|c|c|}
\hline Parameter & Hari-1 & Hari-2 & Hari-6 & Hari-10 & Hari-12 & Hari-18 & Hari-24 \\
\hline $\mathrm{RR}(10-20 \mathrm{x} / \mathrm{m})$ & 28 & 32 & 30 & 24 & 22 & 20 & 16 \\
\hline $\operatorname{Temp}\left(36.5-37.5^{\circ} \mathrm{C}\right)$ & 36,9 & 37,1 & 36,8 & 36,8 & 36,9 & 37,1 & 36,8 \\
\hline $\mathrm{Hb}(12-16 \mathrm{mg} / \mathrm{dL})$ & 14,3 & 13.8 & 15.1 & 15.6 & 17.2 & 15,6 & 15,9 \\
\hline Leukosit (4-10 ribu/ul) & 3 & 3.0 & 4 & 7,3 & 7.1 & 6,9 & 4,7 \\
\hline Trombosit (150-450 ribu/ul) & 185 & 218 & 306 & 183 & 246 & 350 & 227 \\
\hline PT (9.9-13.5 detik) & 11.5 & 12.4 & 12.6 & 10.5 & 10.7 & 15,4 & 12,4 \\
\hline APTT (22.2-37 detik) & 33.7 & 29.7 & 32.6 & 36,9 & 33.3 & 37,5 & 34,0 \\
\hline $\operatorname{INR}(<2)$ & 1,06 & 1.16 & 1.18 & 0,97 & 0.97 & 1,44 & 1,14 \\
\hline Ureum $(0-50 \mathrm{mg} / \mathrm{dL})$ & 21 & 16 & 26 & 18 & 24 & 16 & 22 \\
\hline Creatinin $(0,57-1.11 \mathrm{mg} / \mathrm{dL})$ & 0,94 & 0.80 & 0,91 & 0,68 & 0.80 & 0,21 & 0,8 \\
\hline GDS $(<200 \mathrm{mg} / \mathrm{dL})$ & 137 & 190 & 125 & & 100 & 132 & 206 \\
\hline SGOT (5-34 U/L) & 108 & 114 & 75 & 33 & 25 & 25 & 23 \\
\hline SGPT (0-55 U/L) & 130 & 137 & 82 & 73 & 43 & 35 & 51 \\
\hline Albumin $(3,5-5.2 \mathrm{gr} / \mathrm{dL})$ & 3,3 & 3,1 & & & & 3,5 & 4,2 \\
\hline Natrium (136-145 Meq/L) & 135 & 128 & 132 & 134 & 135 & 136 & 131 \\
\hline Kalium (3,5-5,1 Meq/L) & 3,7 & 4,0 & 4,2 & 3,8 & 4.2 & 4,1 & 4,5 \\
\hline Clorida (98-107 Meq/L) & 106 & 100 & 100 & 107 & 101 & 103 & 100 \\
\hline $\mathrm{O}_{2}$ Saturasi (75-99 \%) & 95 & 95 & 97 & 98 & 99 & & \\
\hline P/F Ratio & 118 & 130 & 124 & 140 & 413 & & \\
\hline LDH (125-220 U/L) & & 963 & & & 634 & & 509 \\
\hline $\mathrm{CRP}(<5 \mathrm{mg} / \mathrm{dL})$ & 40,7 & 140 & & & 1,6 & 1,6 & 1,2 \\
\hline Ferritin (4-204 ng/dL) & 1800 & & & & 340,6 & 56,5 & \\
\hline D-Dimer $(<2$ mg/L) & & $<0,19$ & & & 1,19 & 0,2 & \\
\hline
\end{tabular}

Volume 12, Nomor 3, Tahun 2020 
Keterangan: RR, respiration rate; PT, protrombin time; APTT, activated partial thromboplastin time; GDS, gula darah sewaktu; SGOT, serum glutamic oxaloacetic transaminase, SGPT, serum glutamic pyruvic transaminase; $\mathrm{LDH}$, lactate dehydrogenase; CRP, C-reactive protein.

\section{KASUS 4}

Pasien laki-laki, usia 61 tahun, berat badan $73 \mathrm{~kg}$, terkonfirmasi COVID-19 dengan pemeriksaan RT-PCR positif. Keluhan pasien adalah demam dan batuk dialami sejak 14 hari sebelum masuk rumah sakit.

Kondisi pasien saat masuk ICU sadar penuh namun tampak hipoksia. Sesak napas dengan RR 30-35 x/m, HR $115 \mathrm{x} / \mathrm{m}$, dengan $\mathrm{SpO}_{2} 85 \%$ dengan $\mathrm{O}_{2}$ NRM 15 lpm. Work of breathing (WOB) meningkat dengan gejala keringat dingin dan gelisah, pernapasan abdominal dan retraksi suprasternal. Diputuskan untuk perawatan langsung ke ICU dengan penggunaan ventilator, namun keluarga dan pasien memutuskan untuk menolak terapi menggunakan ventilasi mekanik. Pasien akhirnya dirawat menggunakan HFNC 60 lpm dan $\mathrm{FiO}_{2}$ 90\%.

Hari perawatan ke-1 di ICU pasien diberikan terapi COVID-19 sesuai tingkat keparahan penyakit yaitu oksigenasi HFNC, protokol terapi standar COVID-19, dan heparin SC dosis 5000 IU per 12 jam. Pasien segera mendapatkan TCZ pada hari perawatan ke-1, dengan dosis $400 \mathrm{mg}$ di ulang 12 jam kemudian. Kondisi pasien semakin memburuk, terjadi penurunan kesadaran dan pasien meninggal setelah 36 jam dirawat di ruang ICU.

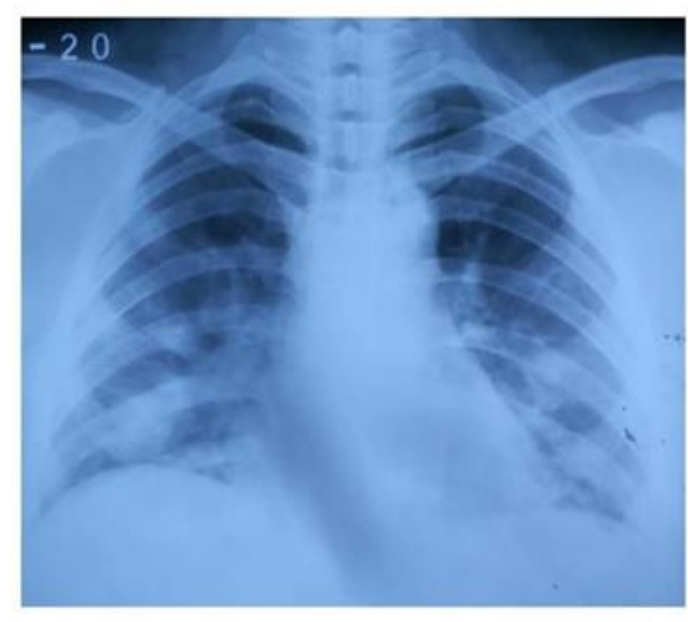

Unit Gawat Darurat

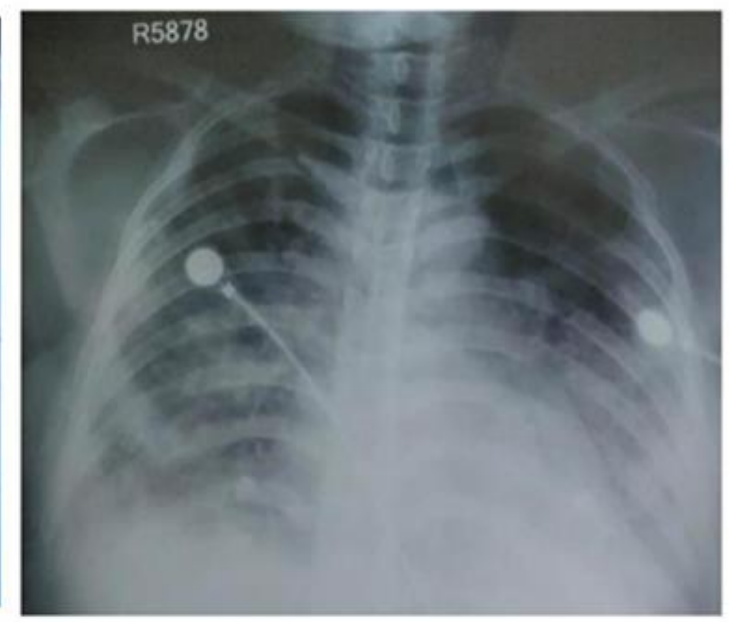

Hari Perawatan-1

Gambar 4. Ronsen toraks evaluasi pasien kasus 4 
Tabel 4. Parameter klinis dan laboratorium kasus 4

\begin{tabular}{lcc}
\hline Parameter & Hari-1 & Hari-2 \\
\hline RR $(10-20 \times / \mathrm{m})$ & 35 & 38 \\
Temp $\left(36.5-37.5 \mathrm{O}_{\mathrm{C}}\right)$ & 37,1 & 37,1 \\
\hline Hb $(12-16 \mathrm{mg} / \mathrm{dL})$ & 16,7 & 14,2 \\
Leukosit $(4-10 \mathrm{ribu} / \mathrm{ul})$ & 12,9 & 12,8 \\
Trombosit $(150-450 \mathrm{ribu} / \mathrm{ul})$ & 187 & \\
\hline PT $(9.9-13.5 \mathrm{detik})$ & 16,8 & \\
APTT $(22.2-37$ detik$)$ & 22,5 & 33 \\
INR $(<2)$ & 1,47 & 1,1 \\
\hline Ureum $(0-50 \mathrm{mg} / \mathrm{dL})$ & 41 & 182 \\
Creatinin $(0,57-1.11 \mathrm{mg} / \mathrm{dL})$ & 1,3 & 64 \\
GDS $(<200 \mathrm{mg} / \mathrm{dL})$ & 114 & 94 \\
SGOT $(5-34 \mathrm{U} / \mathrm{L})$ & 72 & 3,3 \\
SGPT $(0-55 \mathrm{U} / \mathrm{L})$ & 118 & 132 \\
Albumin $(3,5-5.2 \mathrm{gr} / \mathrm{dL})$ & 3,3 & 3,8 \\
Natrium $(136-145 \mathrm{Meq} / \mathrm{L})$ & 135 & 105 \\
Kalium $(3,5-5,1 \mathrm{Meq} / \mathrm{L})$ & 3,5 & 87 \\
Clorida $(98-107 \mathrm{Meq} / \mathrm{L})$ & 3,8 & 60 \\
\hline $\mathrm{O}_{2}$ Saturasi $(75-99 \%)$ & 85 & 30,8 \\
P/F Ratio & 40 & \\
LDH $(125-220 \mathrm{U} / \mathrm{L})$ & 935 & \\
CRP $(<5 \mathrm{mg} / \mathrm{dL})$ & 9 & \\
Ferritin $(4-204 \mathrm{ng} / \mathrm{dL})$ & $>2000$ & \\
D-Dimer (<2 mg/L) & 7,04 & \\
\hline
\end{tabular}

Keterangan: RR, respiration rate; PT, protrombin time; APTT, activated partial thromboplastin time; GDS, gula darah sewaktu; SGOT, serum glutamic oxaloacetic transaminase, SGPT, serum glutamic pyruvic transaminase; $\mathrm{LDH}$, lactate dehydrogenase; CRP, C-reactive protein.

\section{KASUS 5}

Pasien laki-laki, 55 tahun, BB $70 \mathrm{~kg}$, konfirmasi COVID-19 dari hasil pemeriksaan RT-PCR. Pasien datang dengan gejala sedang-berat, sadar penuh, RR 26-28 x/m, HR $110 \mathrm{x} / \mathrm{m}$, dan $\mathrm{SpO}_{2}$ 99\% dengan $\mathrm{O}_{2}$ NRM $15 \mathrm{lpm}$ namun tampak WOB meningkat, pernapasan abdominal dan retraksi suprasternal. Keluhan awal berupa demam, batuk dan nyeri tenggorokan, onset 10 hari.

Pasien dirawat di ruang perawatan biasa selama 24 jam lalu pasien dipindahkan ke ruang ICU karena perburukan kondisi dan ancaman gagal napas.
Selama dirawat di ruang ICU, pasien diberikan terapi COVID-19 sesuai tingkat keparahan penyakit yaitu oksigenasi HFNC flow $60 \mathrm{lpm}, \mathrm{FiO}_{2}$ 90\%, protokol terapi standar COVID-19, dan heparin SC dosis 5000 IU per 12 jam. Pasien baru mendapatkan TCZ pada hari perawatan ke-5 atau setelah dirawat 4 hari di ICU dengan dua kali pemberian dosis $400 \mathrm{mg}$ di ulang 12 jam kemudian. Pasien tidak mengalami perbaikan klinis, cenderung semakin memburuk. Pasien meninggal setelah 6 hari dirawat di ICU. 


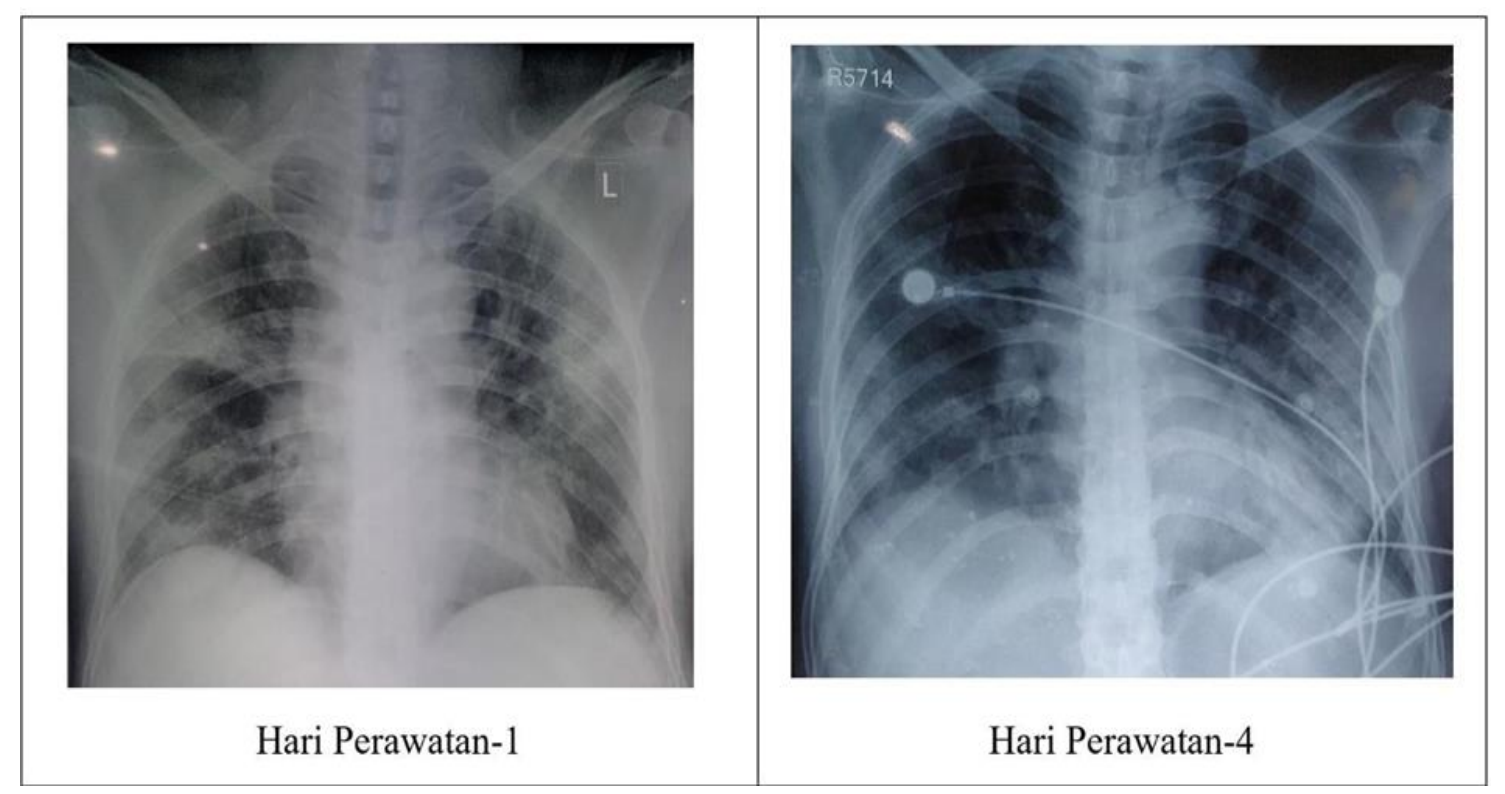

Gambar 5. Ronsen toraks evaluasi pasien kasus 5

Tabel 5. Parameter klinis dan laboratorium kasus 5

\begin{tabular}{|c|c|c|c|c|c|c|}
\hline Parameter & Hari-1 & Hari-2 & Hari-3 & Hari-4 & Hari-5 & Hari-6 \\
\hline RR (10-20 x / m) & 28 & 35 & 30 & 32 & 35 & 38 \\
\hline $\operatorname{Temp}\left(36.5-37.5^{\circ} \mathrm{C}\right)$ & 36,8 & 36,9 & 37,4 & 38,5 & 39,0 & 39,2 \\
\hline $\mathrm{Hb}(12-16 \mathrm{mg} / \mathrm{dL})$ & 14,5 & 13,0 & & & 11,7 & \\
\hline Leukosit (4-10 ribu/ul) & 3,9 & 4,3 & & & 9,2 & \\
\hline Trombosit (150-450 ribu/ul) & 160 & 198 & & & 218 & \\
\hline PT (9.9-13.5 detik) & 11,1 & 10,5 & 12,9 & 11,3 & 12,8 & 10,9 \\
\hline APTT (22.2-37 detik) & 33,9 & 31,3 & 29,1 & 26,7 & 27,7 & 26,4 \\
\hline $\operatorname{INR}(<2)$ & 0,97 & 0,95 & 1,2 & 1,05 & 1,2 & 1,01 \\
\hline Ureum $(0-50 \mathrm{mg} / \mathrm{dL})$ & 44 & 36 & & & 30 & \\
\hline Creatinin $(0,57-1.11 \mathrm{mg} / \mathrm{dL})$ & 0,99 & 1,05 & & & 0,7 & \\
\hline $\operatorname{GDS}(<200 \mathrm{mg} / \mathrm{dL})$ & & 101 & & & 106 & \\
\hline SGOT (5-34 U/L) & & 64 & & & 44 & \\
\hline SGPT $(0-55 \mathrm{U} / \mathrm{L})$ & & 24 & & & 18 & \\
\hline Albumin $(3,5-5.2 \mathrm{gr} / \mathrm{dL})$ & & 3,3 & & & 2,7 & \\
\hline Natrium (136-145 Meq/L) & 124 & 132 & & & 138 & \\
\hline Kalium $(3,5-5,1 \mathrm{Meq} / \mathrm{L})$ & 4,6 & 4,7 & & & 4,3 & \\
\hline Clorida (98-107 Meq/L) & 104 & 104 & & & 110 & \\
\hline $\mathrm{O}_{2}$ Saturasi $(75-99 \%)$ & 95 & 87 & 94 & 91 & 87 & 80 \\
\hline $\mathrm{P} / \mathrm{F}$ Ratio & 145 & 120 & 70 & 61,5 & 35,5 & 41,1 \\
\hline LDH (125-220 U/L) & 1015 & 939 & & & 955 & \\
\hline $\mathrm{CRP}(<5 \mathrm{mg} / \mathrm{dL})$ & 163 & 165 & & & 226 & \\
\hline Ferritin (4-204 ng/dL) & & 1776 & & & $>2000$ & \\
\hline $\mathrm{D}-\operatorname{Dimer}(<2 \mathrm{mg} / \mathrm{L})$ & & 1,28 & & & 7,08 & \\
\hline
\end{tabular}

Keterangan: RR, respiration rate; PT, protrombin time; APTT, activated partial thromboplastin time; GDS, gula darah sewaktu; SGOT, serum glutamic oxaloacetic transaminase, SGPT, serum glutamic pyruvic transaminase; $\mathrm{LDH}$, lactate dehydrogenase; $\mathrm{CRP}$, C-reactive protein. 


\section{PEMBAHASAN}

COVID-19 merupakan penyakit pernapasan akut yang disebabkan oleh virus SARS-CoV-2. Manifestasi klinis dan derajat keparahannya bervariasi dan melibatkan banyak organ. Derajat penyakitnya di kategorikan menjadi asimtomatik, ringan, sedang, berat dan kritis, dimana derajat berat dan kritis memiliki gambaran klinis serius yaitu adanya pneumonia, hipoksemia, ARDS, hingga gejala ekstrapulmoner seperti syok, ensefalopati, disfungsi koagulasi sampai gangguan ginjal dan jantung. ${ }^{12}$

Virus SARS-CoV-2 ini utamanya menyerang sel epitel jalan napas dan alveolar, sel endotel vaskular, dan makrofag di paru yang mengekspresikan angiotensinconverting enzyme 2 (ACE2), yang merupakan reseptor target untuk SARSCoV-2. Selanjutnya ekspresi ACE2 di paru akan berkurang, yang menyebabkan acute lung injury dan disfungsi renin-angiotensin system (RAS). Selain itu akan terjadi proses pyroptosis, yaitu kematian sel terprogram akibat inflamasi cytopathic virus (virus yang dapat mengubah struktur lalu membunuh sel) yang akhirnya menyebabkan respons inflamasi lokal. ${ }^{12}$

Proses inflamasi akan berlanjut dengan peningkatan sekresi sitokin dan kemokin proinflamasi seperti IL-1 $\beta$, IL6 , interferon gamma (IFN $\gamma$ ), monocyte chemoattractant protein 1 (MCP1), IFNy-induced protein 10 (IP-10), dan lain-lain ke dalam sirkulasi. ${ }^{4}$ Pada kasus COVID- 19 berat dan kritis terjadi proses pelepasan sitokin dan kemokin proinflamasi ini secara tidak terkendali yang disebut sebagai cytokine release syndrome (CRS) atau badai sitokin. Pelepasan sitokin termasuk IL-6 ini akan meningkatkan permeabilitas vaskuler, influx cairan dan sel darah berlebih ke alveolus yang menyebabakan gangguan oksigenasi, ARDS, dan lung injury. ${ }^{13}$ Fenomena CRS inilah yang diduga kuat sebagai proses patologi terjadinya ARDS, disfungsi koagulasi, dan beragam proses kerusakan organ yang menjadi penyebab morbiditas dan mortalitas COVID-19. Berdasarkan patogenesis penyakit diatas maka muncul hipotesis yang sekarang sedang diteliti untuk pengobatan COVID-19 yaitu TCZ, yang merupakan golongan IL-6 inhibitor. ${ }^{12}$

Pada serial kasus ini, kami memberikan TCZ sebagai terapi tambahan pada protokol standar pengobatan COVID-19 berdasarkan derajat keparahan penyakit yang sama, namun ada perbedaan pada waktu pemberiannya yang dihitung dari onset munculnya gejala yang diderita kelima pasien. Semua pasien tersebut diberikan TCZ tanpa terapi tambahan lain seperti plasma konvalesen ataupun intravena imunoglobulin (IVIg).

Dari serial kasus kami, 4 pasien merupakan laki-laki, 1 pasien merupakan perempuan. Dari kategori usia 4 pasien kategori usia 46-59 tahun, 1 pasien kategori $>60$ tahun. Berdasarkan data nasional yang dikeluarkan oleh pemerintah Indonesia sampai 11 September 2020, perbandingan pasien COVID-19 lakilaki dan wanita adalah 51,6\% laki-laki dan 48,4 \% wanita. Untuk kategori usia, persentase pasien umur 46-59 yang positif COVID-19 adalah 24,5\%, sedangkan kategori >60 tahun persentasenya adalah $11 \% .^{14}$ Dari 5 pasien ini, 3 pasien bisa dipindahkan dari ruang ICU dan akhirnya dipulangkan (kasus 1-3), sedangkan 2 pasien meninggal di ICU (kasus 4-5). Perbandingan pasien meninggal ini tidak bisa dijadikan patokan, namun 
berdasarkan data pendahuluan yang pernah diteliti oleh Quah et al, tingkat kematian pasien COVID-19 yang dirawat di ICU adalah $25,7 \% .{ }^{15}$

Kelima pasien ini mendapatkan IL-6 inhibitor TCZ dengan dosis yang sama yaitu $400 \mathrm{mg}$ per pemberian, dua kali pemberian dengan jeda waktu 12 jam. Semua pasien diberikan TCZ pada awal perawatan, kecuali kasus-5 yang diberikan TCZ pada hari perawatan ke5. Satu pasien yang diberikan TCZ pada hari onset gejala ke-7 (kasus-2), 2 pasien pada hari onset ke-10 (kasus 1 dan 3) dan 2 pasien pada hari onset ke-14 (kasus-4 dan 5). Pemberian TCZ kurang dari 10 hari setelah onset gejala timbul (kasus 1, 2 dan 3) memperlihatkan hubungan yang bermakna antara penurunan level biomarker inflamasi dan perbaikan klinis pasien. Hal yang sebaliknya terjadi pada pemberian TCZ setelah onset gejala timbul lebih dari 10 hari (kasus 4 dan 5). Kedua pasien tersebut tidak mengalami perbaikan klinis dan tren parameter inflamasi tidak dapat diketahui karena pasien meninggal. Grafik hubungan antara timing pemberian TCZ terhadap tren parameter inflamasi, perbaikan klinis berdasarkan: frekuensi napas, saturasi oksigen dan $\mathrm{PaO}_{2}$, serta lama perawatan ICU dari masing-masing pasien dapat terlihat pada Gambar 6.

Beberapa laporan terkait penggunaan TCZ pada pasien COVID-19 sudah diterbitkan dan menunjukkan hasil yang menjanjikan. Salah satunya penelitian yang dilakukan di Cina oleh $\mathrm{Xu}$ et al yang mengevaluasi 21 pasien yang diberikan TCZ. Dari 21 pasien, 4 pasien merupakan pasien kritis dan hanya 1 yang membutuhkan ventilasi mekanik. Semua pasien menunjukkan perbaikan dan tidak ada pasien yang meninggal. ${ }^{16}$ Saat ini, kriteria kandidat ideal untuk terapi IL-6 masih belum disepakati. Secara umum case series oleh $\mathrm{Xu}$ et al dapat menjadi patokan. Kriteria pasien yang dapat menjadi kandidat pemberian terapi IL-6 inhibitor adalah: ${ }^{16}$ (1) Pneumonia Berat, dengan hipoksemia, $\mathrm{SpO}_{2}<94 \%$ saat bernapas udara bebas, takipnea $(\mathrm{RR}>30 \mathrm{x} / \mathrm{m})$ atau $\mathrm{PaO}_{2} / \mathrm{FiO}_{2}$ ratio < 300; (2) Pneumonia kritis, yaitu pasien yang memerlukan bantuan ventilasi mekanik, dalam keadaan syok dan gagal multiorgan yang memerlukan perawatan ICU.

Dari kriteria diatas kelima pasien yang kami laporkan, semuanya masuk dalam kriteria kandidat pasien yang dapat diberikan terapi IL-6 inhibitor.

Pada serial kasus ini, pemberian TCZ berbeda 'timing' pemberiannya jika dihitung dari mulai munculnya onset gejala, 1 pasien (kasus-2) pada hari ke-7 onset, 2 pasien (kasus 1 dan 3) pada hari ke-10 onset, dan 2 pasien (kasus 4-5) pada hari onset ke-14. Terdapat perbedaan outcome pada pasien terkait timing pemberian TCZ. Hal ini bisa disebabkan oleh kadar IL-6 yang sudah berproses lebih lama sehingga sudah terjadi proses CRS yang lebih luas. ${ }^{15}$ Untuk Gambaran perjalanan penyakit dan pendekatan terapi COVID-19 berdasarkan onset penyakit terangkum di Gambar 7. 

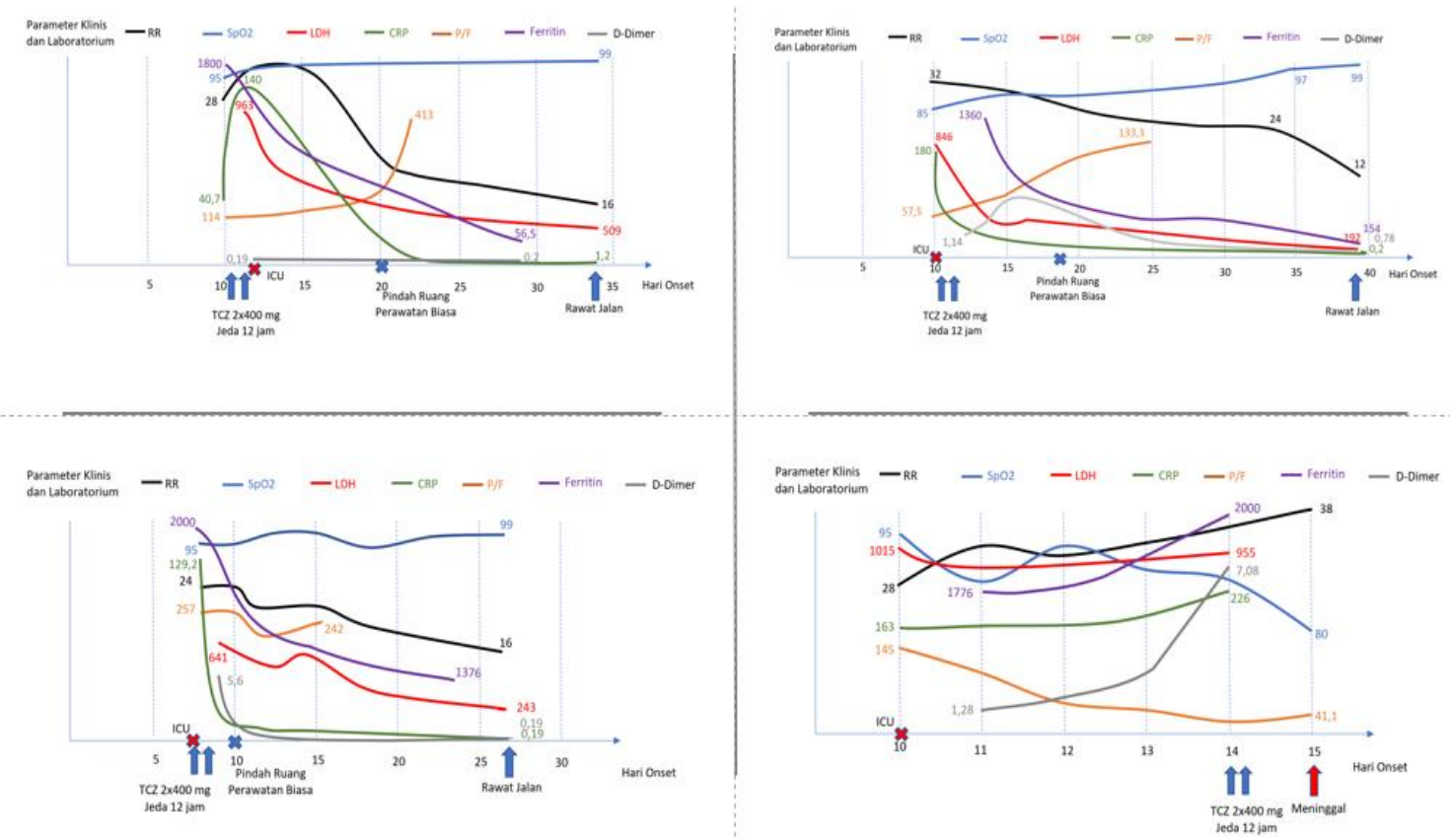

Gambar 6. Grafik timing pemberian TCZ terhadap tren parameter inflamasi, perbaikan klinis berdasarkan: frekuensi napas, saturasi oksigen dan $\mathrm{PaO}_{2}$, serta lama perawatan ICU. Pemberian TCZ kurang dari 10 hari setelah onset klinis muncul memperlihatkan penurunan parameter inflamasi yang disertai dengan perbaikan klinis pasien dan kebutuhan perawatan di ICU yang lebih singkat (A. Kasus 3. TCZ diberikan hari ke 10 onset klinis, perawatan di ICU selama 8 hari. B. Kasus 1. TCZ diberikan hari ke 10 onset klinis, perawatan di ICU selama 8 hari. C. Kasus 2. TCZ diberikan hari ke 7 onset klinis, perawatan di ICU selama 2 hari). Sedangkan pasien yang mendapat terapi TCZ setelah lebih dari 10 hari onset klinis, tidak terlihat adanya perbaikan klinis dan tren parameter inflamasi tidak diketahui dikarenakan pasien meninggal (D. Kasus 5. Kasus 4 pasien meninggal saat tiba di ICU).

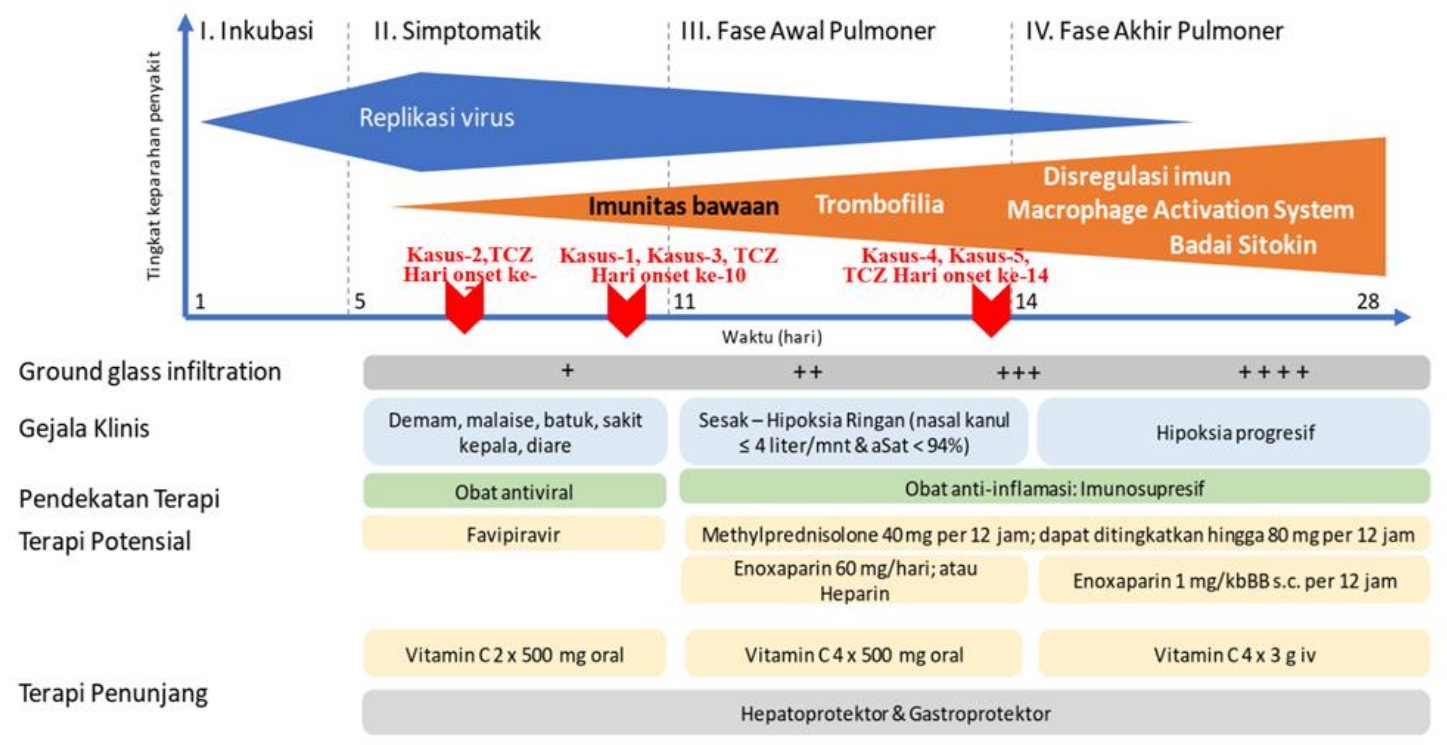

Gambar 7. Fase perjalanan penyakit dan pendekatan terapi pasien COVID-19 ${ }^{17}$

Volume 12, Nomor 3, Tahun 2020 
IL-6 adalah suatu pro-inflammatory cytokine yang diproduksi berbagai jenis sel, diantaranya limfosit, monosit, dan fibroblast. Infeksi yang terkait Corona Virus SARS memicu pelepasan IL-6 pada sel epitel bronkial. Kenaikan kadar IL-6 dapat menjadi mediator yang penting terjadinya severe systemic inflammatory response. ${ }^{18}$ Sebuah penelitian oleh Tobias et al memberikan hasil bahwa cut off kadar IL-6 80 pg/mL merupakan indikator kuat prediksi terjadinya gagal napas dan kematian. ${ }^{19}$ Penelitian oleh Zeming et al membandingkan dan menganalisis derajat keparahan penyakit melalui CTScan toraks dengan kadar IL-6 menyebutkan bahwa pada pasien akan mencapai puncak keparahan penyakit dan kadar IL-6 pada hari ke-20 sampai dengan hari ke-24. ${ }^{13}$

Inflamasi sistemik dan gagal napas hipoksik pada pasien COVID-19 disebabkan oleh meningkatnya pelepasan sitokin yang bisa dideteksi selain dengan mengukur IL-6, juga dapat diukur dengan menghitung kadar CRP, D-Dimer, Ferritin dan $\mathrm{LDH}^{20}$ Karena tidak tersedianya pemeriksaan kadar IL6 , maka kami mengasumsikan terjadinya CRS berdasarkan kenaikan kadar CRP, D-dimer, ferritin dan LDH. Kenaikan biomarker dan gejala klinis pneumonia inilah yang dapat menjadi dasar alasan pemberian TCZ pada pasien COVID-19. Seperti penelitian yang dilakukan oleh Sciascia dkk, di Italia, yang menguji penggunaan off label TCZ pada pasien COVID-19 derajat berat. Sciascia dkk, melakukan penelitian dengan kriteria inklusi : ${ }^{21}$ (1) Pasien positif COVID-19 berdasarkan RT-PCR; (2) Keterlibatan gangguan berat paru yang dinilai dengan $\mathrm{SpO}_{2}<93 \%$ saat bernapas udara bebas, dan atau $\mathrm{PaO}_{2} / \mathrm{FiO}_{2}$ ratio < 300; (3) tiga dari kriteria terpenuhi : $\mathrm{CRP}>10 \mathrm{x}$ nilai normal, ferritin $>1000 \mathrm{ng} / \mathrm{ml}$, D-Dimer
$>10$ kali nilai normal, atau $\mathrm{LDH}>2$ kali nilai normal.

Pada laporan kasus kami, diawal perawatan semua pasien mengalami peningkatan CRP. Pada 2 pasien (Kasus4 dan Kasus-5) yang meninggal peningkatan CRP tetap terjadi selama perawatan, namun 3 pasien yang berhasil dipulangkan (Kasus 1-3) mengalami penurunan kadar CRP sampai pada nilai normal pada pemeriksaan terakhir sebelum pasien dipulangkan. CRP adalah protein plasma yang diproduksi liver dan pelepasannya dipicu oleh berbagai mediator inflamasi salah satunya IL-6. ${ }^{22}$ Walaupun bersifat nonspesifik namun kadar CRP sering digunakan untuk menilai keparahan penyakit COVID-19. Hal ini telah dilaporkan dalam 2 penelitian retrospective cohort study di China oleh Qin et al dan Liu et al, dimana kesimpulan kedua penelitian tersebut adalah kadar CRP merupakan indikator kuat yang dapat merefleksikan keberadaan dan derajat keparahan penyakit COVID- $19 .{ }^{23,24}$

Data kadar D-Dimer pada kelima pasien memiliki pola yang bervariasi. Pada kasus 1 sempat terjadi peningkatan kadar D-Dimer $>2 \mathrm{mg} / \mathrm{L}$ di tengah perawatan, kasus 2 dan 3 stabil dengan kadar Ddimer normal $<2 \mathrm{mg} / \mathrm{L}$, namun pada saat pemeriksaan terakhir semua kadar Ddimer pasien normal $<2 \mathrm{mg} / \mathrm{L}$ saat dipulangkan. Pada grup pasien yang meninggal, kadar D-Dimer keduanya memiliki nilai $>7 \mathrm{mg} / \mathrm{L}$. D-Dimer berasal dari hasil lisis cross-linked fibrin, dimana kenaikan kadarnya mengindikasikan terjadinya aktivasi koagulasi dan fibrinolysis. ${ }^{25}$ Pada pasien COVID-19 terjadi proses hiperkoagulasi yang diakibatkan inflamasi. Peningkatan sitokin pro inflamasi (IL-1, IL-6) dan hipoksia akibat ARDS akan 
mengaktivasi sel endotel dan ekspresi tissue factor. Peningkatan ekspresi tissue factor ini akan memicu aktivasi jalur koagulasi ekstrinsik. ${ }^{26}$ Sebuah penelitian retrospective cohort study oleh Zhang et al di China mengatakan kadar D-Dimer $>2 \mathrm{mg} / \mathrm{L}$ meningkatkan mortalitas pada pasien COVID-19 dimana penelitian tersebut juga mengatakan kadar D-Dimer $>2 \mathrm{mg} / \mathrm{L}$ pada saat pertama dirawat dapat menjadi prediktor untuk inhospital mortality pasien COVID-19. ${ }^{27}$

Data ferritin pasien juga menunjukkan hasil yang bervariasi pada awal perawatan, pemeriksaan ferritin semua pasien memiliki nilai $>1000 \mathrm{ng} / \mathrm{dL}$. Pada pasien yang berhasil pulang, kasus ke-1 dan 3 menunjukkan penurunan sampai ke batas normal yaitu $<200 \mathrm{ng} / \mathrm{dL}$, dan kasus 2 mengalami penurunan namun masih $>1000 \mathrm{ng} / \mathrm{dL}$. Pada pasien meninggal konsisten kadar feritin $>2000$ ng/dL (kasus 4 dan 5). Kadar ferritin secara independen berkaitan dengan kejadian ARDS, mortalitas dan COVID19 derajat kritis. Tingginya kadar ferritin dapat mengarah pada secondary hemophagocytic lymphohisticytosis (sHLH). Kejadian sHLH ini adalah kondisi hiperinflamasi yang memiliki karakteristik cytokine storm yang menyebabkan kegagalan multi organ. ${ }^{28}$

Data LDH konsisten pada 2 pasien meninggal (kasus 4-5) dimana ditemukan kadar LDH yang tinggi antara 900-1000 dan tidak ada penurunan setelah pemberian terapi. Untuk kelompok pasien pulang, pada awal perawatan ditemukan kadar tinggi LDH namun tidak setinggi kasus 4-5. Setelah pasien mendapat terapi untuk COVID-19 terjadi penurunan kadar LDH namun hingga pasien dipulangkan LDH, penurunan LDH tidak mencapai batas normal. LDH merupakan enzim yang merubah piruvat menjadi laktat pada metabolisme glukosa. Sekresi LDH dipicu oleh nekrosis membran sel yang mungkin menandakan infeksi virus atau kerusakan paru walaupun munkin tidak spesifik disebabkan oleh penyakit COVID-19. ${ }^{29}$ Sebuah penelitian oleh Guan et al, yang melibatkan 1099 pasien memberikan bukti mendukung bahwa peningkatan LDH berhubungan dengan derajat kerusakan jaringan. ${ }^{30}$

Respons terpenting untuk menilai efek terapi TCZ ini adalah penilaian perbaikan klinis, walaupun masih terdapat alasan kuat untuk menggunakan nilai biomarker seperti yang disebut di atas sebagai panduan, baik untuk seleksi pasien maupun respons terapi mengingat pemeriksaan IL-6 masih belum tersedia di banyak rumah sakit. Namun jika menilai kadar IL-6 sebgai acuan, perlu dilakukan pengawasan yang lebih ketat karena pada beberapa penelitian disebutkan bahwa dapat terjadi peningkatan IL-6 setelah pemberian TCZ. ${ }^{31}$

\section{KESIMPULAN}

Telah kami laporkan serial kasus dari 5 pasien yang mendapatkan tambahan terapi TCZ berdasarkan klinis terjadinya badai sitokin dan peningkatan kadar CRP, D-dimer, ferritin, LDH karena tidak adanya data kadar IL-6. Kelima pasien ini memiliki derajat keparahan penyakit yang sama tetapi berbeda dari segi onset penyakit dan saat pemberian TCZ. Tiga pasien bertahan hidup dan pulang ke rumah sedangkan 2 lainnya meninggal dunia. Dari analisis kami, TCZ memberikan efek terapi jika diberikan pada onset gejala kurang dari 10 hari tetapi hal ini masih perlu dibuktikan lebih lanjut dengan penelitian yang menggunakan jumlah pasien yang cukup. 
DAFTAR PUSTAKA

1. World Health Organization. WHO Coronavirus Diseases (COVID-19) Dashboard [Internet]. 2020 [cited 2020 Sep 12]. Available from: https://covid19.who.int/

2. COVID-19 GTPP. Situasi Virus COVID-19 di Indonesia [Internet]. 2020 [cited 2020 Sep 12]. Available from: https://covid19.go.id/

3. $\mathrm{Wu} \mathrm{Z}$, McGoogan JM. Characteristics of and Important Lessons from the Coronavirus Disease 2019 (COVID-19) Outbreak in China: Summary of a Report of 72314 Cases from the Chinese Center for Disease Control and Prevention. Vol. 323, JAMA Journal of the American Medical Association. 2020. p. 1239-42

4. Huang C, Wang Y, Li X, Ren L, Zhao J, Hu Y, et al. Clinical features of patients infected with 2019 novel coronavirus in Wuhan, China. Lancet. 2020;395(10223):497-506

5. Betts BC, Young JW. Less Can Be More When Targeting Interleukin6-Mediated Cytokine Release Syndrome in Coronavirus Disease 2019. Crit Care Explor. 2020;2(6):e0138

6. Chen $\mathrm{G}, \mathrm{Wu} \mathrm{D}$, Guo W, Cao Y, Huang D, Wang $\mathrm{H}$, et al. Clinical and immunological features of severe and moderate coronavirus disease 2019. J Clin Invest. 2020;130(5):2620-9

7. Zhou Y, Fu B, Zheng X, Wang D, Zhao C, Qi Y, et al. Pathogenic Tcells and inflammatory monocytes incite inflammatory storms in severe COVID-19 patients. Natl Sci Rev. 2020;7(6):998-1002

8. Wang L, Peng X, Wang ZH, Cai J, Zhou FC. Tocilizumab in the treatment of a critical COVID-19 patient: A case report. Eur Rev Med Pharmacol Sci. 2020;24(10):5783-7
9. Hitawala A, Kumar S, Gopalakrishna K V. Early Use of Tocilizumab May Prevent Clinical Deterioration in Select COVID-19 Patients: A Case Series. Cureus. 2020;12(7)

10. Scott LJ. Tocilizumab: A Review in Rheumatoid Arthritis. Drugs. 2017;77(17):1865-79

11. Tadepalli S, Vanjarapu JMR, De Dona A, Cheriyath P, Nookala V. The Role of Interleukin-6 Inhibitors in the Treatment of COVID-19 Infections: A Case Series. Cureus. 2020;12(6)

12. Atal S, Fatima Z. IL-6 Inhibitors in the Treatment of Serious COVID19: A Promising Therapy? Pharmaceut Med. 2020;(0123456789)

13. Liu Z, Li J, Chen D, Gao R, Zeng W, Chen S, et al. Dynamic Interleukin6 Level Changes as a Prognostic Indicator in Patients With COVID$19 . \quad$ Front Pharmacol. 2020;11(July):1-11

14. KEMENKES. Peta Sebaran COVID-19 di Indonesia [Internet]. 2020 [cited 2020 Sep 12]. Available from: https://covid19.go.id/petasebaran

15. Quah P, Li A, Phua J, Phua J. Mortality rates of patients with COVID-19 in the intensive care unit: A systematic review of the emerging literature. Crit Care. 2020;24(1):1-4

16. Xu X, Han M, Li T, Sun W, Wang $\mathrm{D}, \mathrm{Fu} \mathrm{B}$, et al. Effective treatment of severe COVID-19 patients with tocilizumab. Proc Natl Acad Sci U S A. 2020;117(20):10970-5

17. BUMN, Pertamina, Indonesia Healthcare Corporation. Buku Pegangan Pencegahan \& Penatalaksanaan COVID-19. Revisi-1. Jakarta; 2020 
18. Yoshikawa T, Hill T, Li K, Peters CJ, Tseng C-TK. Severe Acute Respiratory Syndrome (SARS) Coronavirus-Induced Lung Epithelial Cytokines Exacerbate SARS Pathogenesis by Modulating Intrinsic Functions of MonocyteDerived Macrophages and Dendritic Cells. J Virol. 2009;83(7):3039-48

19. Herold T, Jurinovic V, Arnreich C, Lipworth BJ, Hellmuth JC, Bergwelt-Baildon $\mathrm{M}$ von, et al. Elevated levels of IL-6 and CRP predict the need for mechanical ventilation in COVID-19. J Allergy Clin Immunol [Internet]. 2020;146(1):128-136.e4. Available from:

https://doi.org/10.1016/j.jaci.2020.0 5.008

20. Zhou F, Yu T, Du R, Fan G, Liu Y, Liu Z, et al. Clinical course and risk factors for mortality of adult inpatients with COVID-19 in Wuhan, China: a retrospective cohort study. Lancet. 2020;395(10229):1054-62

21. Sciascia S, Aprà F, Baffa A, Baldovino S, Boaro D, Boero R, et al. Pilot prospective open, singlearm multicentre study on off-label use of tocilizumab in patients with severe COVID-19. Clin Exp Rheumatol. 2020;38(3):529-32

22. Gong J, Dong H, Xia SQ, Huang YZ, Wang D, Zhao Y, et al. Correlation Analysis Between Disease Severity and Inflammationrelated Parameters in Patients with COVID-19 Pneumonia. 2020;

23. Qin C, Zhou L, Hu Z, Zhang S, Yang $\mathrm{S}$, Tao Y, et al. Dysregulation of Immune Response in Patients With Coronavirus 2019 (COVID-19) in Wuhan, China. Clin Infect Dis. 2020;71(15):762-8

24. Liu F, Li L, Xu M Da, Wu J, Luo D, Zhu YS, et al. Prognostic value of interleukin-6, C-reactive protein, and procalcitonin in patients with COVID-19. J Clin Virol. 2020;127

25. Kermali M, Khalsa RK, Pillai K, Ismail Z, Harky A. The role of biomarkers in diagnosis of COVID19 - A systematic review. Vol. 254, Life Sciences. 2020

26. Hajra A, Mathai SV, Ball S, Bandyopadhyay D, Veyseh $M$, Chakraborty S, et al. Management of Thrombotic Complications in COVID-19: An Update. Drugs [Internet]. 2020;(0123456789). Available from: https://doi.org/10.1007/s40265-02001377-x

27. Zhang L, Yan X, Fan Q, Liu H, Liu $\mathrm{X}$, Liu $\mathrm{Z}$, et al. D-dimer levels on admission to predict in-hospital mortality in patients with Covid-19. J Thromb Haemost. 2020;18(6):1324-9

28. Huang I, Pranata R, Lim MA, Oehadian A, Alisjahbana B. Creactive protein, procalcitonin, $\mathrm{D}$ dimer, and ferritin in severe coronavirus disease-2019: a metaanalysis. Ther Adv Respir Dis. 2020;14:1-14

29. Han Y, Zhang H, Mu S, Wei W, Jin $\mathrm{C}$, Tong $\mathrm{C}$, et al. Lactate dehydrogenase, an independent risk factor of severe COVID-19 patients: A retrospective and observational study. Aging (Albany NY). 2020;12(12):11245-58

30. Guan W, Ni Z, Hu Y, Liang W, Ou $\mathrm{C}, \mathrm{He} \mathrm{J}$, et al. Clinical characteristics of coronavirus disease 2019 in China. N Engl J Med. 2020;382(18):1708-20

31. Calabrese C, Rajendram P, Sacha G, Calabrese L. Practical aspects of targeting IL-6 in COVID-19 disease: Posted april 21, 2020. Cleve Clin J Med. 2020;87(5):1-5 